\title{
Effects of Colchicines on Cadmium Accumulation of Post Generation of Bidens pilosa
}

\author{
Yahui Xin ${ }^{1, a}$, Lei Liu ${ }^{2, b}$, Xun Wang ${ }^{3, c}$, Wei Jiang ${ }^{4, d}$ and Lijin Lin ${ }^{3, e^{*}}$ \\ ${ }^{1}$ College of Horticulture, Sichuan Agricultural University, Chengdu, Sichuan, China \\ ${ }^{2}$ Chengdu Academy of Agriculture and Forestry Sciences, Chengdu, Sichuan, China \\ ${ }^{3}$ Institute of Pomology and Olericulture, Sichuan Agricultural University, Chengdu, Sichuan, China \\ ${ }^{4}$ College of Chemistry and Life Science, Chengdu Normal University, Chengdu, Sichuan, China \\ a1059389559@qq.com, bskyskyskylover@163.com.cn, ${ }^{\mathrm{c} 35744023 @ q q . c o m, ~}$ \\ d1399945180@qq.com, ${ }^{\mathrm{e}}$ llj800924@163.com
}

${ }^{*}$ Corresponding author. Yahui Xin, Lei Liu and Xun Wang contributed equally to this work.

Keywords: Bidens pilosa; Colchicines; Cadmium; Post generation

Abstract: The pot experiment was conducted to study the effects of colchicines on cadmium $(\mathrm{Cd})$ accumulation of post generation of Bidens pilosa. The $0.3 \%$ of colchicines treating with $48 \mathrm{~h}$ did not change the number of chromosomes in two ecotypes (farmland ecotype and mining ecotype) of $B$. pilosa. The colchicines treatments increased the biomass, photosynthetic pigment content, $\mathrm{Cd}$ contents and $\mathrm{Cd}$ accumulation of post generation of $\mathrm{B}$. pilosa compared with their respective control. For farmland ecotype of post generation of B. pilosa, the Cd accumulation amount in roots and shoots increased by $16.30 \%$ and $29.82 \%$, respectively compared with the control; for mining ecotype of post generation of $B$. pilosa, the Cd accumulation amount in roots and shoots increased by $2.67 \%$ and $25.01 \%$, respectively compared with the control. Therefore, the colchicines could promote the growth and $\mathrm{Cd}$ accumulation of post generation of B. pilosa.

\section{Introduction}

Cadmium (Cd) is one of the most toxic heavy metals, and is widely present in the soil [1]. The industrial waste, excessive mining and irrational agricultural measures have led to the increase of $\mathrm{Cd}$ concentration in soil [2]. As a non-essential element, the excessive accumulation of $\mathrm{Cd}$ in the crop will lead to a decline in crop yield and quality, and which will enter into the human body through the food chain [3]. So, reducing the uptake and accumulation of $\mathrm{Cd}$ in crops and ensuring the safety of agricultural production is imminent.

Bidens pilosa is a Cd-hyperaccumulator [4] with strong resistance and fecundity, and a broad distribution worldwide [5]. Compared with other hyperaccumulator or accumulator species such as Solanum nigrum [6] and Siegesbeckia orientalis [7], the remediation ability of B. pilosa is low and requires improvement. To enhance the potential of $B$. pilosa to remediate Cd-contaminated soil, two ecotypes (farmland ecotype and mining ecotype) of B. pilos $a$ were treated with $0.3 \%$ of colchicines. The aim of the study was to determine whether the colchicines could enhance the phytoremediation ability of post generation of $B$. pilos $a$, and to provide a reference for improving the phytoremediation ability of other hyperaccumulator or accumulator species.

\section{Materials and Methods}

Materials. Seeds of two ecotypes (mining and farmland) of B. pilosa were collected from the Tangjiashan lead-zinc mine $\left(29^{\circ} 24^{\prime} \mathrm{N}, 102^{\circ} 38^{\prime} \mathrm{E}\right.$, with typical dry-hot valley climate) and farmland of the Ya'an campus farm of the Sichuan Agricultural University $\left(29^{\circ} 59^{\prime} \mathrm{N}, 102^{\circ} 59^{\prime} \mathrm{E}\right.$, with humid subtropical monsoon climate), respectively, in August 2013. The seeds were air dried and stored at $4{ }^{\circ} \mathrm{C}$. 
Colchicines Treatment. The seeds of two ecotypes of B. pilosa were sown in farmland of the Ya'an campus farm in March 2014. When the first pairs of plant euphyllas expanded, $0.3 \%$ of colchicines treated the top of stems, and used the plastic film covering to keep moisture for $48 \mathrm{~h}$. When the seeds of $B$. pilosa mature, they were collected, air dried and stored at $4{ }^{\circ} \mathrm{C}$. After microscopic examining the chromosome of post generation of B. pilosa, the $0.3 \%$ of colchicines treating with $48 \mathrm{~h}$ did not change the number of chromosomes in two ecotypes of B. pilosa.

Experimental Design. The experiment was conducted in the greenhouse of the Ya'an campus farm from February to June 2015. The soil samples were air dried and passed through a 5-mm sieve. Three kilograms of the air-dried soil was weighed into each polyethylene pot $(18 \mathrm{~cm}$ high and $21 \mathrm{~cm}$ in diameter). $\mathrm{Cd}$ was added to soils as $\mathrm{CdCl}_{2} \cdot 2.5 \mathrm{H}_{2} \mathrm{O}$ at $10 \mathrm{mg} / \mathrm{kg}$ [8] in February 2015. The soil moisture was maintained at $80 \%$ of field capacity for 2 months. The seeds of two ecotypes of post generation of B. pilosa were sown in farmland of the Ya'an campus farm in March 2015. Four uniform seedlings of $B$. pilosa (two pairs of euphyllas expanded) were transplanted into each pot in April 2015, and the soil moisture content was maintained at $80 \%$ of field capacity from the time the plants were transplanted into the pots until the time the plants were harvested. Treatments were replicated four times. 2 months later (June 2015), the upper mature leaves of B. pilos $a$ were collected to determine the photosynthetic pigment (chlorophyll $a$, chlorophyll $b$, total chlorophyll, and carotenoid) contents [9]. The plants were then gently removed from the soil, and the roots, stems, and leaves were washed with deionized water and dried at $80^{\circ} \mathrm{C}$ to constant weight for dry weight and $\mathrm{Cd}$ content determination [10].

Statistical analyses. Statistical analyses were conducted using SPSS 13.0 statistical software (IBM, Chicago, IL, USA). Data were analyzed by one-way analysis of variance with least significant difference (LSD) at the $\mathrm{p}=0.05$ confidence level. The following calculated were used: translocation factor $(\mathrm{TF})=\mathrm{Cd}$ content in shoots/ $\mathrm{Cd}$ content in roots [11]; translocation accumulation factor (TAF) $=(\mathrm{Cd}$ content in shoots $\times$ biomass in shoots $) /(\mathrm{Cd}$ contents in roots $\times$ biomass in roots $)[12]$.

\section{Results and Discussion}

Biomass. The biomass of mining ecotype of $B$. pilosa was higher than the farmland ecotype of $B$. pilosa (Table 1). The colchicines treatments increased the root, stem, leaf and shoot biomasses of two ecotypes of B. pilosa compared with their respective control. For the farmland ecotype of B. pilosa, the colchicines treatments increased the root and shoot biomasses by $12.58 \%(p<0.05)$ and $10.29 \%$ $(p<0.05)$ respectively compared with the control. For mining ecotype of B. pilosa, the colchicines treatments increased the root and shoot biomasses by $1.66 \%(p>0.05)$ and $11.39 \%(p<0.05)$ respectively compared with control. The root/ shoot ratio of mining ecotype of $B$. pilosa was higher than the farmland ecotype of $B$. pilosa (Table 1). The colchicines treatments improved the root/ shoot ratio of farmland ecotype of $B$. Pilosa, and reduced the root/ shoot ratio of mining ecotype of $B$. pilosa.

Table 1 Biomass of post generation of Bidens pilosa

\begin{tabular}{llllcc}
\hline \multicolumn{1}{c}{ Treatments } & \multicolumn{1}{c}{$\begin{array}{c}\text { Roots } \\
\text { (g/plant })\end{array}$} & \multicolumn{1}{c}{$\begin{array}{c}\text { Stems } \\
\text { (g/plant) }\end{array}$} & \multicolumn{1}{c}{$\begin{array}{c}\text { leaves } \\
\text { (g/plant })\end{array}$} & $\begin{array}{c}\text { Shoots } \\
\text { (g/plant) }\end{array}$ & $\begin{array}{c}\text { Root/ shoot } \\
\text { ratio }\end{array}$ \\
\hline Farmland control & $0.453 \pm 0.0071 \mathrm{c}$ & $0.913 \pm 0.0071 \mathrm{~d}$ & $1.118 \pm 0.011 \mathrm{c}$ & $2.031 \pm 0.018 \mathrm{c}$ & 0.223 \\
Mining control & $0.541 \pm 0.014 \mathrm{ab}$ & $0.971 \pm 0.0071 \mathrm{c}$ & $1.215 \pm 0.021 \mathrm{bc}$ & $2.186 \pm 0.028 \mathrm{~b}$ & 0.248 \\
Farmland treatment & $0.510 \pm 0.014 \mathrm{~b}$ & $1.001 \pm 0.013 \mathrm{~b}$ & $1.239 \pm 0.027 \mathrm{ab}$ & $2.240 \pm 0.040 \mathrm{~b}$ & 0.228 \\
Mining treatment & $0.550 \pm 0.013 \mathrm{a}$ & $1.140 \pm 0.014 \mathrm{a}$ & $1.295 \pm 0.021 \mathrm{a}$ & $2.435 \pm 0.035 \mathrm{a}$ & 0.226 \\
\hline
\end{tabular}

Photosynthetic Pigment Content. The chlorophyll $a$ content in mining ecotype of $B$. pilosa was higher than the farmland ecotype of $B$. pilosa, but there were no significant differences of the chlorophyll $b$, total chlorophyll and carotenoid contents between two ecotypes of $B$. pilosa (Table 2). The colchicines treatments increased the contents of chlorophyll $a$, chlorophyll $b$, total chlorophyll 
and carotenoid in two ecotypes of B. pilosa. The colchicines treatments increased total chlorophyll contents in farmland ecotype of B. pilosa by $39.25 \%(p<0.05)$ compared with the control, and by $28.02(p<0.05)$ for that in mining ecotype of B. pilos $a$ compared with the control. The chlorophyll $\mathrm{a} / \mathrm{b}$ of mining ecotype of $B$. pilosa was also higher than the farmland ecotype of B. pilosa (Table 2). The colchicines treatments reduced the chlorophyll $\mathrm{a} / \mathrm{b}$ of two ecotypes of $B$. pilosa compared with their respective control.

Table 2 Photosynthetic pigment content in post generation of Bidens pilosa

\begin{tabular}{lccccc}
\hline \multicolumn{1}{c}{ Treatments } & $\begin{array}{c}\text { Chlorophyll } a \\
(\mathrm{mg} / \mathrm{g})\end{array}$ & $\begin{array}{c}\text { Chlorophyll } b \\
(\mathrm{mg} / \mathrm{g})\end{array}$ & $\begin{array}{c}\text { Total chlorophyll } \\
(\mathrm{mg} / \mathrm{g})\end{array}$ & $\begin{array}{c}\text { Chlorophyll } \\
\mathrm{a} / \mathrm{b}\end{array}$ & $\begin{array}{c}\text { Carotenoid } \\
(\mathrm{mg} / \mathrm{g})\end{array}$ \\
\hline Farmland control & $1.233 \pm 0.025 \mathrm{c}$ & $0.357 \pm 0.012 \mathrm{~b}$ & $1.590 \pm 0.037 \mathrm{~b}$ & 3.454 & $0.439 \pm 0.009 \mathrm{~b}$ \\
Mining control & $1.357 \pm 0.003 \mathrm{~b}$ & $0.374 \pm 0.050 \mathrm{~b}$ & $1.731 \pm 0.080 \mathrm{~b}$ & 3.628 & $0.468 \pm 0.001 \mathrm{~b}$ \\
Farmland treatment & $1.636 \pm 0.048 \mathrm{a}$ & $0.578 \pm 0.032 \mathrm{a}$ & $2.214 \pm 0.080 \mathrm{a}$ & 2.834 & $0.603 \pm 0.023 \mathrm{a}$ \\
Mining treatment & $1.656 \pm 0.011 \mathrm{a}$ & $0.560 \pm 0.036 \mathrm{a}$ & $2.216 \pm 0.047 \mathrm{a}$ & 2.957 & $0.596 \pm 0.008 \mathrm{a}$ \\
\hline
\end{tabular}

Cadmium Content. The Cd contents in roots, stems, leaves and shoots of mining ecotype of $B$. pilosa were higher than the farmland ecotype of B. pilosa (Table 3). The colchicines treatments increased the $\mathrm{Cd}$ contents in roots, stems, leaves and shoots of two ecotypes of B. pilosa compared with their respective control. For the farmland ecotype of $B$. pilosa, the colchicines treatments increased the $\mathrm{Cd}$ contents in roots and shoots by $3.30 \%(p<0.05)$ and $17.92 \%(p>0.05)$ respectively compared with the control. For mining ecotype of $B$. pilosa, the colchicines treatments increased the Cd contents in roots and shoots by $0.99 \%(p<0.05)$ and $12.23 \%(p<0.05)$ respectively compared with control. The TF of mining ecotype of $B$. pilosa was higher than the farmland ecotype of $B$. pilosa (Table 3). The colchicines treatments enhanced the TF of two ecotypes of B. pilosa compared with their respective control.

Table 3 Cadmium content in post generation of Bidens pilosa

\begin{tabular}{lccccc}
\hline \multicolumn{1}{c}{ Treatments } & $\begin{array}{c}\text { Roots } \\
(\mathrm{mg} / \mathrm{kg})\end{array}$ & $\begin{array}{c}\text { Stems } \\
(\mathrm{mg} / \mathrm{kg})\end{array}$ & $\begin{array}{c}\text { Leaves } \\
(\mathrm{mg} / \mathrm{kg})\end{array}$ & $\begin{array}{c}\text { Shoots } \\
(\mathrm{mg} / \mathrm{kg})\end{array}$ & TF \\
\hline Farmland control & $187.15 \pm 4.04 \mathrm{a}$ & $75.01 \pm 1.73 \mathrm{~b}$ & $112.41 \pm 3.66 \mathrm{c}$ & $95.60 \pm 2.77 \mathrm{c}$ & 0.511 \\
Mining control & $195.32 \pm 6.00 \mathrm{a}$ & $77.86 \pm 0.20 \mathrm{ab}$ & $131.23 \pm 1.85 \mathrm{~b}$ & $107.52 \pm 0.98 \mathrm{~b}$ & 0.550 \\
Farmland treatment & $193.32 \pm 4.71 \mathrm{a}$ & $80.75 \pm 3.48 \mathrm{ab}$ & $138.56 \pm 3.80 \mathrm{~b}$ & $112.73 \pm 3.53 \mathrm{ab}$ & 0.583 \\
Mining treatment & $197.26 \pm 3.89 \mathrm{a}$ & $84.84 \pm 3.05 \mathrm{a}$ & $152.21 \pm 4.45 \mathrm{a}$ & $120.67 \pm 3.73 \mathrm{a}$ & 0.612 \\
\hline
\end{tabular}

Cadmium Accumulation. Compared with the farmland ecotype of B. pilosa, the $\mathrm{Cd}$ accumulation amounts in roots, stems, leaves and shoots of mining ecotype of B. pilosa were higher (Table 4). The colchicines treatments increased the $\mathrm{Cd}$ accumulation amounts in roots, stems, leaves and shoots of two ecotypes of $B$. pilosa compared with their respective control. For the farmland ecotype of $B$. pilosa, the colchicines treatments increased the $\mathrm{Cd}$ accumulation amounts in roots and shoots by $16.30 \%(p<0.05)$ and $29.82 \%(p>0.05)$ respectively compared with the control. For mining ecotype of B. pilosa, the colchicines treatments increased the $\mathrm{Cd}$ accumulation amounts in roots and shoots by $2.67 \%(p<0.05)$ and $25.01 \%(p<0.05)$ respectively compared with control. The TAF of mining ecotype of $B$. pilosa was lower than the farmland ecotype of B. pilosa (Table 3). The colchicines treatments enhanced the TAF of two ecotypes of $B$. pilosa compared with their respective control.

\section{Conclusions}

The colchicines treatments did not change the number of chromosomes in two ecotypes (farmland ecotype and mining ecotype) of B. pilosa. The colchicines treatments increased the biomass, photosynthetic pigment content, $\mathrm{Cd}$ contents and $\mathrm{Cd}$ accumulation of post generation of $\mathrm{B}$. pilosa 
compared with their respective control. For farmland ecotype of post generation of B. pilosa, the Cd accumulation in roots and shoots increased by $16.3 \%$ and $29.8 \%$, respectively compared with the control; for mining ecotype of post generation of $B$. pilosa, the Cd accumulation in roots and shoots increased by $2.7 \%$ and $25.0 \%$, respectively compared with the control. Therefore, the colchicines could promote the growth and $\mathrm{Cd}$ accumulation of post generation of $\mathrm{B}$. pilosa, which could use to enhance the phytoremediation ability of $B$. pilosa for Cd-contaminated soil.

Table 4 Cadmium accumulation amount in post generation of Bidens pilosa

\begin{tabular}{lccccc}
\hline \multicolumn{1}{c}{ Treatments } & $\begin{array}{c}\text { Roots } \\
(\mu \mathrm{g} / \text { plant })\end{array}$ & $\begin{array}{c}\text { Stems } \\
(\mu \mathrm{g} / \text { plant })\end{array}$ & $\begin{array}{c}\text { Leaves } \\
(\mu \mathrm{g} / \text { plant })\end{array}$ & $\begin{array}{c}\text { Shoots } \\
(\mu \mathrm{g} / \text { plant })\end{array}$ & TAF \\
\hline Farmland control & $84.78 \pm 0.51 \mathrm{~d}$ & $68.48 \pm 1.04 \mathrm{~d}$ & $125.67 \pm 2.82 \mathrm{~d}$ & $194.51 \pm 3.87 \mathrm{~d}$ & 2.29 \\
Mining control & $105.67 \pm 0.48 \mathrm{~b}$ & $75.60 \pm 0.36 \mathrm{c}$ & $159.44 \pm 0.53 \mathrm{c}$ & $235.04 \pm 0.89 \mathrm{c}$ & 2.22 \\
Farmland treatment & $98.59 \pm 0.33 \mathrm{c}$ & $80.83 \pm 2.45 \mathrm{~b}$ & $171.68 \pm 0.99 \mathrm{~b}$ & $252.51 \pm 3.44 \mathrm{~b}$ & 2.56 \\
Mining treatment & $108.49 \pm 0.37 \mathrm{a}$ & $96.72 \pm 2.28 \mathrm{a}$ & $197.11 \pm 2.54 \mathrm{a}$ & $293.83 \pm 4.82 \mathrm{a}$ & 2.71 \\
\hline
\end{tabular}

\section{Acknowledgements}

This work was financially supported by the Application Infrastructure Project of Science and Technology Department of Sichuan Province (2016JY0258).

\section{References}

[1] Z.W. Li, Z.Z. Wang, Y.M. Zhang and X.J. Xing: Chinese Journal of Applied Ecology Vol. 11, (2000), p. 31.

[2] State Environmental Protection Administration: Environmental Protection Vol. 30, (2003), p. 3.

[3] Y.J. Cui, Z.Q. Zhao, W.J. Liu, S.B. Chen and Y.G. Zhu: Chinese Journal of Ecology Vol. 18, (2000), p. 2133.

[4] Y.B. Sun, Q.X. Zhou, L.Wang and W.T. Liu: Journal of Hazardous Materials Vol. 161, (2009), p. 808.

[5] S.L. Guo and Y.H. Li: Resources Science Vol. 18, (1996), p. 48.

[6] S.H. Wei, Q.X. Zhou, X. Wang, K.S. Zhang, G.L. Guo and Q.Y. Ma Lena: Chinese Science Bulletin Vol. 50, (2005), p. 33.

[7] S.R. Zhang, H.C. Lin, L.J. Deng, G.S. Gong, Y.X. Jia, X.X. Xu, T. Li, Y.Li and H. Chen: Ecological Engineering Vol. 51, (2013), p. 133.

[8] L. Lin, M. Liao, L. Mei, J. Cheng, J. Liu, L. Luo and Y. Liu: Environmental Progress \& Sustainable Energy Vol. 33, (2014), p. 1251.

[9] Z.B. Hao, J. Chang and Z. Xu: Plant Physiology Experiment (Harbin Institute of Technology Press, China 2004).

[10] S.D. Bao: Agrochemical Soil Analysis (3rd edition, China Agriculture Press, Beijing, China 2000).

[11] F. Rastmanesh, F. Moore and B. Keshavarzi: Bulletin of Environmental Contamination and Toxicology Vol. 85, (2010), p. 515.

[12] F.H. Nie: Ecology and Environment Vol. 14, (2005), p. 163. 